\title{
Irony AND HUMOR In PRINCESS SMaRTYPantS
}

\begin{abstract}
The aim of this paper is to analyse the postmodern picturebook Princess Smartypants, written and illustrated by Babette Cole, taking into account the relationship between the words and the images and the incongruities posed not only between the text and the images but also between this tale and other fairytales. Generic conventions, background knowledge and intertextuality are key aspects to identify and/or to solve the incongruities, which provoke irony and humor.
\end{abstract}

Keywords

Postmodern picturebook; irony; humor; intertextuality; incongruity

\section{Introduction}

Princess Smartypants, written and illustrated by Babette Cole, has been studied by different scholars focusing on a variety of topics, such as feminism (Davies 1989), gender roles, representation of the feminine or how traditional stereotypes are challenged (Sidall 1997, Shanks 2008). It has also been studied as a teaching tool to develop critical thinking (Roche 2015), to create values awareness and to teach vocabulary, among other aspects. A third line of research has been the focus on the relationship between text and images (Nikolajeva and Scott 2001, Moya and Pinar 2009). These studies mention the humorous dimension of the story but little attention has been paid to the way humor and irony are produced. In Princess Smartypants there are "readerly gaps" created not just between words and pictures but also by intertextuality and intervisuality (Beauvais 2015). This paper aims at analysing how the gaps are filled. In most of the cases there are incongruities. The identification and in some cases resolution of the incongruity usually fill 
the existent gap and provoke irony and humor. In order to identify the incongruities, intertextuality, background knowledge, generic conventions and awareness of the allusions to other fairytales are necessary.

The paper is structured in different sections. The first one deals with an introduction to postmodern picturebooks and literature related to word and image interaction. The second section provides a brief outline of the literature on irony and humor and a mention to intertextuality and background knowledge. In the third section, a detailed analysis of Princess Smartypants is carried out, highlighting the incongruities between text and images and also the incongruities between this story and other fairytales. The paper ends with the conclusions and the references.

\subsection{An introduction to picturebooks}

Picturebooks represent a unique visual and literary artform that engages young and old readers in many levels of learning and pleasure (Wolfenbarger and Sipe 2007). From a semiotic point of view, picturebooks convey their messages using two separate sets of signs, the iconic and the conventional. Iconic signs are those in which the sign or signifier is a direct representation of its signified, that is, a picture and the real object it is trying to represent. On the contrary, in conventional signs, the signifier does not have any relation with its signified. These two kinds of signs are responsible for two different types of communication: the verbal and the visual. Furthermore, as Nikolajeva and Scott (2001: 6) point out, picturebooks are iconotexts, "an inseparable entity of word and image, which cooperate to convey a message". The primary function of conventional signs is to narrate, as also do the pictures, considered as iconic signs which represent events, states, characters, etc. The relation between both kinds of signs gives rise to different interpretations.

Bearing these two definitions in mind, it may seem that iconic signs and words have had the same consideration among scholars dealing with children's picturebooks. The latter have been considered as education vehicles that allow socialization and language acquisition (Sell 2002: 87), as objects for art history or have been analysed focusing on their thematic and stylistic diversity (Feaver 1977). In these studies, the visual aspects have been considered as secondary, and their relationship to the verbal text has been practically ignored. Fortunately, there has been a considerable change in the last 30 years and scholars have focused their attention on the relationship between word and image (Nodelman 1988; Moebius 1986; Nikolajeva and Scott 2000; Lewis 2006 [2001]; Wolfenbarger and Sipe 2007; Painter et al. 2013; Moya and Pinar 2008, 2009; Moya 2014). As Nodelman (1988: 196) states, a picturebook can tell three different stories at the same time; the one we extract from the words, the one conveyed by the pictures and the one resulting from the interaction of both words and pictures. This is what Sipe has called "synergy", that is, "the production of two or more agents, substances, etc. of a combined effect greater than the sum of their separate effects" (Sipe 1998: 
98). In picturebooks this synergistic relationship means that the story depends on the interaction of the written text and the image. Readers respond to each element of the book and can form new meanings from the text or the image or both. As Bader (1976: 1) points out, "a picturebook is text, illustrations, total design [...]. As an art form it hinges on the interdependence of pictures and words, on the simultaneous display of two facing pages, and on the drama of turning the page". In the following paragraphs we move one step forward and describe postmodern picturebooks, under which category Princess Smartypants is included.

\subsection{Postmodern picturebooks}

In the last few years different researchers have investigated postmodernism in relation to picturebooks (see among others Dresang 1999; Goldstone 1999, 2002; Pantaleo 2004; Lewis 2006 [2001], Sipe and Pantaleo 2008). According to Van Meerbergen (2012), postmodernism is often used as a term to describe certain changes and tendencies which started occurring within Western culture and society during the last half of the 20th century. The fact is that the definition is not really established, and consequently this term is often used and interpreted in different ways (Pantaleo and Sipe 2008). Flieger (1991) summarizes the debate on postmodernism by distinguishing between four main positions: it is seen as either "(i) a reaction, (ii) a denial, (iii) a residue or (iv) an intensification of modernism" (cited in Pantaleo and Sipe 2008: 1-2). In any case, one central and recurring theme within postmodernism seems to be the establishment of a critical and ironic dialogue with the past (Grieve 1993: 15). If we specifically focus on postmodern picturebooks, Anstey (2002), Goldstone (2002) and Pantaleo and Sipe (2008) propose the following characteristics, even though not necessarily all of them need to be found in each picturebook:

1. Non-traditional plot structure. Pantaleo and Sipe (2008) consider that the breaking of literary traditions and conventions is a typical feature, together with the mixing of reality and fiction. The postmodern picturebook text can further be seen as an open text, i.e. text that invites different interpretations and readings, which in many cases is combined with an open ending or a circular and therefore never ending structure.

2. Use of pictures or text to position the reader to read the text in a particular way, for example, through a character's eyes or point of view.

3. The reader's involvement with constructing the meaning of the text. The reader is often given an active role as a participant in the story as (s)he is expected to connect certain points and to create all sorts of meanings. In some cases, a direct form of interaction between the text and reader is established as the reader is addressed personally and/or is instructed to perform certain tasks.

4. Intertextual references, which require the reader to make connections to other books or knowledge, in order to better understand the text. A book may 
take two or more familiar texts and intertwine them to create a new story. Pantaleo and Sipe (2008) further add that the occurrence of explicit forms of visual intertextuality is combined with play, parody, pastiche and irony, which involve aspects or fragments from other works of art, (well-)known stories and other forms of popular culture "being picked up and combined into a new semiotic unit" (Pantaleo and Sipe 2008: 6).

5. Varied design layout and a variety of styles of illustration (Anstey 2002).

Princess Smartypants meets some of these postmodern features. It breaks literary traditions and conventions. In fact, it is a parodic revision of Cinderella, with a smattering of The Frog Price and Rumplestiltskin also included. The use of intertextual references requires the reader's background knowledge of generic conventions and other fairy tales in order to make the necessary connections and grasp the emerging incongruities. The reader's involvement with constructing the meaning of the text as well as the use of pictures and text to create and transmit meaning are important features in this picturebook. Therefore, the following section deals with literature on word/image interaction and how it works in Princess Smartypants.

\subsection{Word and image interaction in picturebooks}

There are different theories on word and image interaction. Some of the most important ones are (i) the reader-response theory (Iser 1974), (ii) the readeroriented theory (Culler 1975), (iii) the hermeneutic theory (Sell 2002) and (iv) the taxonomy of intersemiotic relations (Nikolajeva and Scott 2001), further developed by Unsworth (2008) and refined by Moya and Pinar (2009).

The reader-response theory is based on the assumption that the reader is the one that produces the meaning of the picturebook: Both words and images leave room for the reader's/viewer's to fill with their experiences, previous knowledge and expectations. This interaction offers the reader/writer infinite possibilities of meaning. On the other hand, Culler's (1975) reader-oriented semiotics starts from the same principles as the previous one, but he goes one step further and claims that the reader needs literary competence in order to decipher meaning. Covers, titles, layout and graphic codes are some of the elements in a picturebook that sometimes need a base of literary and/or cultural knowledge in order to be properly decoded (as we will see in section 3). According to the hermeneutical theory (Sell 2002: 87), the reader must start paying attention to the general and then continue looking at the details, repeating the process once and again in an "eternal circle", called the hermeneutic circle. Applying this theory to picturebooks, the reader should start from any of the two elements (verbal or visual) and then shift his/her attention to the other going back to both of them repeatedly in order to get the different points of view that the author has hidden in both the visual and the verbal text. As Nikolajeva and Scott (2001: 2) point out, "each new re-reading of either words or pictures creates better prerequisites for an adequate interpretation of the whole". 
Nikolajeva and Scott's (2001) taxonomy includes aspects of the above-mentioned theories and adds different kinds of interaction between words and images: (i) symmetrical, (ii) enhancing, (iii) complementary, (iv) counterpoint and (v) contradictory. In Moya and Pinar (2009), this taxonomy is refined and their model differentiates between four different types of intersemiotic relations: symmetrical interaction, ideational complementarity, counterpointing interaction and contradictory interaction (Moya and Pinar 2009: 112; Moya 2014). In symmetrical interaction, words and images are considered to convey the same story, essentially repeating information through different forms of communication. The term ideational complementarity will be used to refer to those cases in which what is represented in images and what is represented in language is different but complementary (Unsworth 2008: 15). Pictures further amplify the meaning of the words, or the words expand upon the images so one of the two modes provides additional information that the other component lacks. Depending on the degree of different information presented, a counterpointing interaction may develop where words and images provide 'alternative information' and collaborate to communicate meanings beyond the scope of either one standing alone. Nikolajeva and Scott $(2000,2001)$ distinguish two types of counterpointing interaction, also adopted by Moya and Pinar (2009): (i) ironic counterpoint and (ii) perspectival counterpoint. In ironic counterpoint, both modes tell similar stories but at the same time, one of them, usually the visual, adds some irony and humor. As Moya (2014: 73) points out, in this type of interaction words and images do not duplicate each other but seem to have a low level of coherence. Perspectival counterpoint occurs when the story is told from a different perspective than what is perceived by a character, and differs from what the reader or the other characters of the tale see. Finally, in contradictory interaction, words and pictures significantly contradict each other in some way or they express entirely different things. In this category, the role of the reader is highlighted as s/he tries to establish and understand all the content presented.

To sum up, word-image interaction leaves room for the readers to fill the gaps with previous knowledge of other fairytales, gender roles and generic conventions; experience on reading fairytales and expectations created either in the visual or textual mode.

\section{Irony and humor}

The relationship between irony and humor is subtle. As Attardo (2001: 122) rightly points out, "humor and irony overlap significantly, but are distinct". What Attardo implies is that in some cases irony is humorous and in some other cases we may find examples of humor which are not ironical. Irony and humor have similarities and differences. Both are based on an incongruity or contrast (Colston and O'Brien 2000: 1563) but while humor consists of a semantic and a pragmatic facet, irony is a purely pragmatic phenomenon (Attardo 2001). The following 
paragraphs provide an outline of the literature on irony and humor and why these concepts are relevant for our study.

As defined by Quintilian (1999), irony is one of the tropes conceived as a way of saying the opposite of what the speaker means. Together with Quintilian, Dr Johnson's (1755) definition of irony as "a mode of speech in which the meaning is contrary to the words" remains the most familiar and influential. Scott (2004: 32) argues that contrast between what is said and what is meant, and contrast in the seeming incongruity of the choice of expression, - in the present case, of text or image - are two characteristics of irony. Traditionally, irony has been considered as a linguistic and literary phenomenon, in particular a discursive strategy presupposing certain previous knowledge (Kümmerling-Meibauer 1999: 15). Sperber and Wilson (1981), Gibbs and O'Brien (1991), Giora (1995, 2000), Attardo (2000) and Yus (2016) are some of the researchers who have studied irony from a linguistic point of view. However, as Kümmerling-Meibauer (1999: 161) points out, there has been little research on irony in the field of visual arts and most specifically in the field of picturebooks. In spite of this, several authors have mentioned the pleasure young children take in looking at ironic picturebooks, seemingly grasping the humorous effects caused by an ironic juxtaposition of texts and pictures (Dombey 1992; Nodelman 1988; Lewis 1996). One of the aims of this paper is to contribute to the studies of (visual) irony in picturebooks and the humorous effect produced in children and adults alike.

Following Attardo (2001: 111), "the ironic meaning is arrived at inferentially and more or less independently from the literal meaning of the utterance". Our assumption is that irony is completely dependent on context, including but not limited to the speaker's intentions and goals. In Grice's sense (1989), the ironical meaning needs to be inferred, never "said" (Attardo 2001: 111). More specifically:

Recognition of irony rarely comes from the words themselves [...], but rather from cues in the conversational context or nonverbal communication of the speaker. The ironic implicatures resulting from such cues merely point to the possibility that the speaker's meaning may be other than that of the literal content of the utterance; other conversational implicatures and semantic considerations can then supply an alternative interpretation (Schaffer 1982: 15).

Some of the defining properties of irony are the following:

- An ideological component, which sets two orders of reality and associated belief systems into conflict with each other.

- A dissembling component, or at least an element of differential awareness, between the ironist-cum-audience and the unwitting victim of irony.

- An incongruity, which alerts the viewer to either the intention or the potential for irony (Scott 2004: 35). 
One may ask how these approaches to irony as an explicitly verbal phenomenon can be applied to the visual medium. Scott (2004) looks at two types of visual irony: word based and wordless. We will focus our attention on word based visual irony.

In word based irony, a conflict comes into play between what the text says and what the surrounding picture shows. In the case of Princess SmartyPants, the conflict is between the words and the images of the picturebook: there is a contrast between what is said and what is shown, a discrepancy between the expectations set up by the words and the images or viceversa. The reader is aware of this discrepancy thanks to background knowledge and intertextuality.

In the context of visual irony, the cues for the recognition of irony are in the visual part and in the relationship established between the visuals and the text. In such cases, the context does not only involve the surrounding images, but also background knowledge and assumptions on fairytales, gender roles and stereotypes to name only a few.

Irony is one of the key factors in postmodern picturebooks (cf. Section 1.2). According to Kümmerling-Meibauer (1999: 162), three possibilities of ironic picturebooks can be differentiated: the ironic content of picturebooks could be produced either (i) by contradiction within the text itself, (ii) by contradiction within the picture itself, or (iii) by contradiction between picture and text. The picturebook under analysis falls in the last category.

This relates well to the concept of ironic counterpoint (mentioned in section 1.3 ) and the incongruity theory of humour which will be presented in the following paragraph, as incongruity may be considered as an indicator of ironic intent. Incongruity depends on knowledge of larger context and background assumptions; that is to say, it is not limited to two conflicting elements within an image, but may occur between the world as depicted in an image and the disruption it causes our own prior world view and preconceptions (Scott 2004: 40). This is the case in Princess SmartyPants, where our preconceptions and assumptions about fairy tales and the associated roles will enter in conflict with the text and the images depicted. Reinterpretation of the evidence from a perspective of greater knowledge is an important component of irony (Scott 2004: 34). In addition, as pointed out in section 1.2., postmodern picturebooks' use of intertextuality and irony are key aspects to take into account.

Little has been said so far about humor. Humor is a universal phenomenon that depends on culture-specific discourses, stereotypes and symbols that surround key themes shared by societies, such as politics, sex, religion or gender among others (Andrew 2012: 11). There are three mainstream approaches to humor: superiority theories, release theories and incongruity theories (cf. Raskin 1985; Yus 2016: 65-66). Whereas the first two types focus "on the content of the jokes and the psychological functions they fulfill", incongruity theories "focus on the specific form or structure that characterizes humorous texts" (El Refaie 2009: 78). The incongruity theory of humour states that humour is perceived at the moment of the realization of an incongruity between a concept involved in a certain 
situation and the real objects thought to be in some relation to the concept. This is the approach to humor we adopt in this paper, as the realization of the incongruities posed in it are expected to make people smile.

\subsection{Irony and humor in Princess Smartypants}

Princess Smartypants tells the story of a princess who does not want to get married and prefers living alone in her castle surrounded by her pets. When her parents force her to find a suitor and marry him, she decides to set her suitors several tasks. The one who is able to accomplish the task will marry her. All the princes fail in the attempt, except for one, who manages to carry out all the tasks successfully. But when Princess Smartypants kisses him he turns into a warty toad. When the other princes get to know about this action, they give up their attempts to win the princess' hand and, as a result, she can live happily with the only company of her pets. Princess Smartypants adds a humorous dimension to the genre of fairy tales (as it defies traditional gender roles) and provides a good example of words and images in ironic counterpoint.

\subsection{Analysis}

Princess Smartypants is a typical 32-page picturebook, made up of occasional doublespreads (five in total; see Figures 3, 4 and 5) and mostly verso and recto illustrations ${ }^{1}$. The layout of doublespreads include, following Nikolajeva's words (2008: 61), "the mutual position of the text and the picture panels, the presence or absence of borders and frames, and the relationship between left-hand page (verso) and right-hand page (recto)". As Nikolajeva (2008: 61) points out,

page layout is essential since in postmodern picturebooks facing pages comprise a single whole even when they depict two different scenes. Nothing can be moved on a doublespread, neither text, nor image, without destroying the synergetic effect of the narrative.

In this paper we will use the term doublespread to name images that belong together in the verso-recto composition. Otherwise, the verso and recto will be treated independently.

32 images have been analysed ${ }^{2}$, the following paragraphs being an attempt to identify Moya and Pinar's (2009) ideational complementarity and counterpointing interaction together with the way irony and humor are produced when the incongruity is resolved. The study focuses on two types of incongruities:

1) Incongruity between this fairytale and other fairytales. Intertextuality plays an important role here as knowledge of other fairytales and gender stereotypes on the part of the reader are necessary to solve the incongruity. 
2) Incongruity between text and image. These incongruities are also present in the first category.

For analytical purposes we have divided the fairytale into three parts. The first one sets the scene, describes Princess Smartypants and tells us what the story is about. In the second part, Princess Smartypants sets different tasks and the prince who is able to accomplish the assigned task will win her hand. This section shows how the different princes try to accomplish the task and how they fail in their attempts. The third part shows how Prince Swashbuckle manages to succeed and the final outcome.

\subsubsection{Incongruities between Princess Smartypants and other fairytales}

This section deals with examples of incongruities between Princess Smartypants and other fairytales and the relationship we can establish with ideational complementarity and ironic counterpoint. Both the text and the visual challenge traditional generic conventions. The content of the language and images is not the one associated to classical tales. Just looking at the coverpage (see Figure 1) the reader realizes that Princess Smartypants is not a classic tale about princesses, but rather a story that defies traditional gender roles (Shanks 2008: 25). On a pink background it reads Princess Smartypants, surrounded by lots of stars, typical of fairytales. However, details of the image tell a completely different story. The only elements related to royalty are a little crown in a tangled mane of hair and the inscription HRHPS (Her Royal Highness Princess Smartypants). The image represents a blond girl, wearing a motorist black suit, driving a Norton motorbike ${ }^{3}$ and carrying a kind of dragon on the back seat. From the amount of smoke going out of the exhaust pipe as well as the wind power, Smartypants is driving at high speed. At this point the reader starts wondering what the story will be about as incongruities have been set up. Black leather is not usually how we imagine a picturebook princess to be attired. In traditional tales dragons and princesses are antipathetic to one another (Sidall 1997). Additionally, after the starry title the reader would normally expect a big carriage with a beautiful and elegant princess inside rather than a motorbike. These facts set up expectations to what will come next in the picturebook and support the assertion that there will be significant differences between the protagonist of this text and those of traditional texts. Upon opening the book, there is a coat of arms. Two small winged dragons flank its sides and a crowned frog sits on top. The shield is blue and is adorned with pink ribbons. The motto on the banner reads, "Smartypants Rulus O.K.us", which is ironic. There is a lack of seriousness in the use of this emblem which provokes humour. In the title page, Princess Smartypants is depicted with a chubby face, wearing old overalls that let us see her white socks and her red slippers. She leads a parade of winged, dragon-creatures. It seems she is directing the reader into the text. These three examples, just before the story begins, anticipate the ironic character of the story, as the expectations set up by the title are incongruent with the images. 


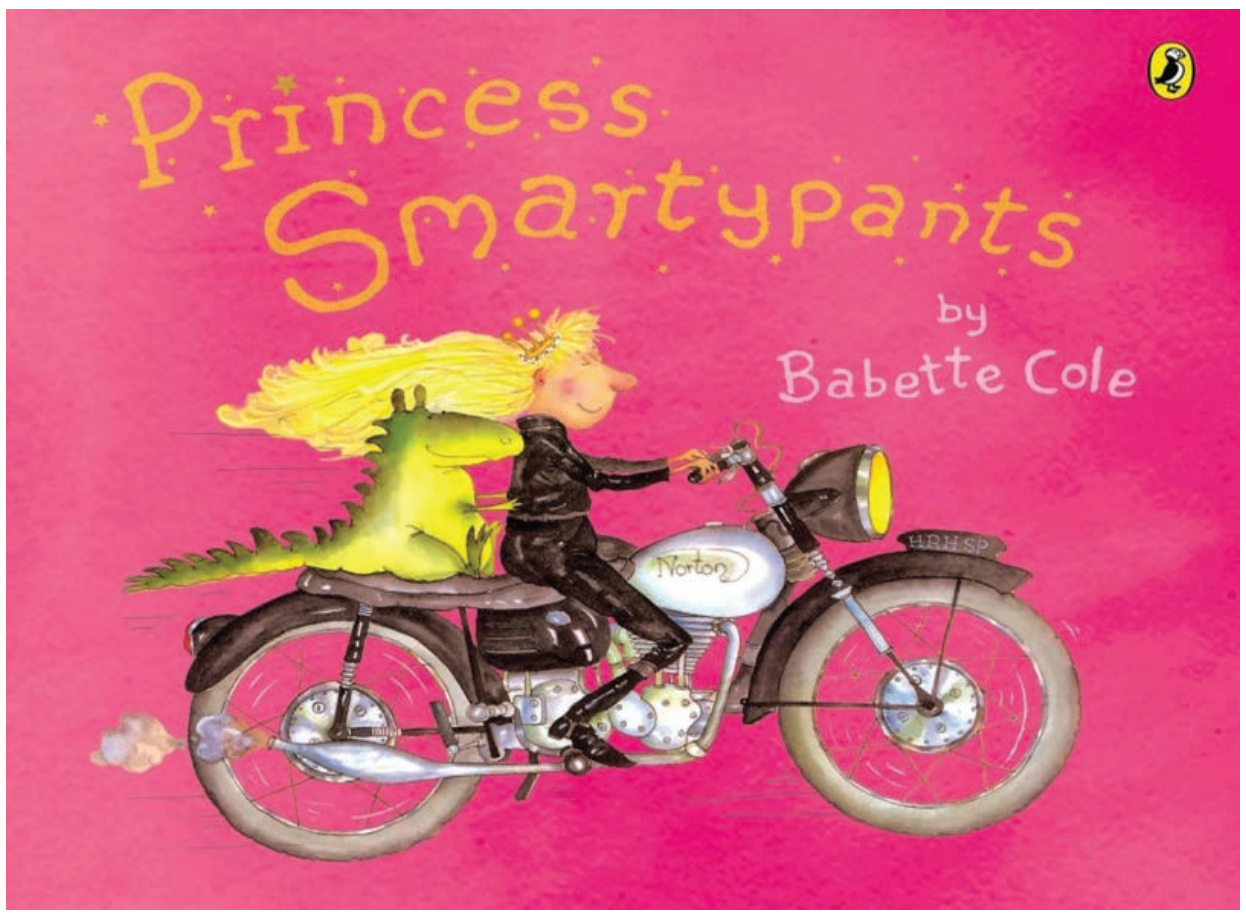

Figure 1. Princess Smartypants front cover

The first opening, which shows us images in a verso/recto distribution, is rich in incongruities. "Princess Smartypants did not want to get married. She enjoyed being a Ms". Cole's approach to nontraditional princesses is straightforward. In the first place, the language used is hardly normal fairytale language. In addition, the images clearly amplify the information transmitted in the textual part as they show us Smartypants' concept of being a Ms and enjoying it: she is lying on the floor, watching horse-riding programmes and surrounded by her pets -her horse is spread comfortably on the sofa, dirty clothes and dishes and litter (a piece of cake, a coke nd a chocolate bar whose brands are not clearly visible but the reader is able to identify, a banana peel and apple cores). These products contribute to the ironic content of the image: While the traditional princess looks after herself and has a healthy and balanced diet, Smartypants does not seem to do so. In the recto (see Figure 2), she is sitting on her throne, wearing the same overalls and slippers and doing her nails. She avoids making eye contact with the three suitors in the image, who are gazing lovingly at her. Cole applies the marks of the traditional princess to her in the textual part "She is very pretty and rich, all the princes wanted her to be their Mrs". The description of her beauty and wealth, together with the captivated princes, align her with the traditional princess (Shanks 2008: 30 ). However, the visuals show a non-traditional image of a princess, challenging the traditional image of princesses (See Figure 2). This is also true in an image 




Figure 2. Princess Smartypants and her suitors

which shows the King and the Queen urging her to find a husband. This would be normal if it were not because Smartypants is wearing her overalls and Wellington boots.

The second opening is a doublespread in which the images expand the meaning transmitted in the text. All Smartypants wants to do is "live in her castle and do exactly as she pleases". The pictures (see Figure 3) show what this entails and transmit irony and humour: she is surrounded by her pets, which are not the kind of pets you would normally find in a house... or palace! Irony and humor once again emerge from contradicting our expectations about fairytales.

The last part of the story provides another clear example of this type of incongruities. Once Prince Swashbuckle manages to carry out all the tasks successfully, Smartypants has lost her bet, "so she gave him a magic kiss..." (see Figure 6). Although the princess is depicted as a tomboy wearing overalls earlier in the book, when it comes time for her to kiss the prince she becomes more feminine. By depicting her as a typical princess, Cole is setting the viewer up to believe that the kiss will end in her marrying the prince (Shanks 2008: 31). The image does not tell us anything different from the text, apparently there is no contradiction between both modes. However, the word "magic" is predicting that something unexpected will happen. In order to create a bigger impact, the mistery is solved 


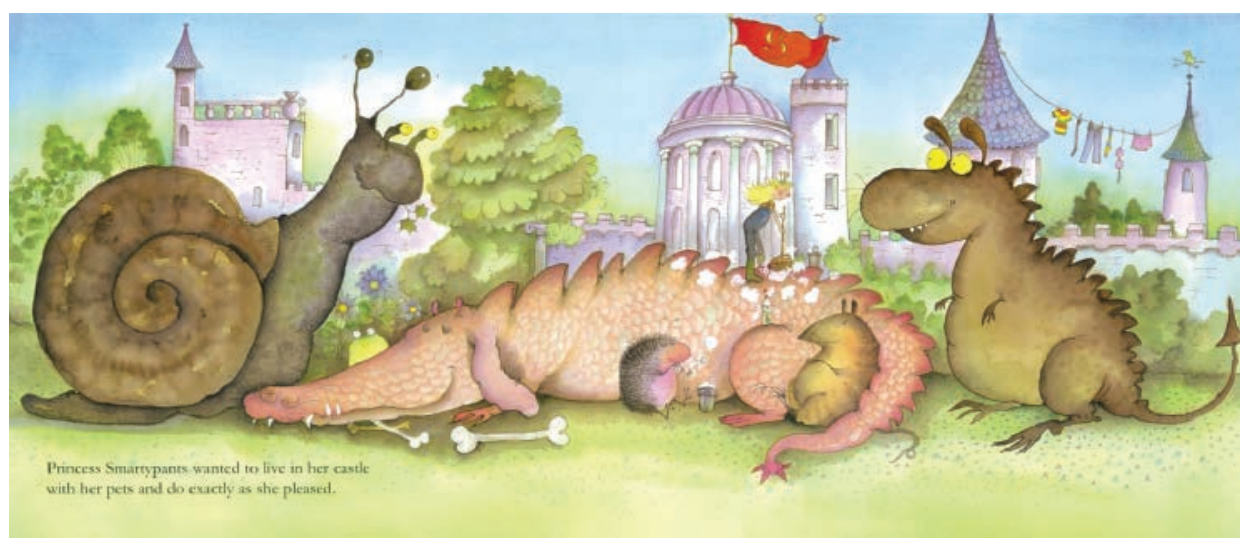

Figure 3. Princess Smartypants' pets

in the verso, when we turn the page. "And he turned into a gigantic warty toad". Instead of the image of a Royal Wedding, we find a toad wearing the prince's accessories. The irony lies in the fact that the picturebook is telling us the opposite of traditional fairytales, in which princesses kiss toads hoping to turn them into handsome princes. Here, the princess' kiss turns the prince into a toad. Being a toad, "Prince Swashbuckle left in a big hurry". The image shows this farewell: we find a toad driving a royal car and a happy princess waving him from the tower of her castle. According to Shanks (2008: 31), Princess Smartypants' reliance on magic to escape marriage, despite her determination and wit, is a regression in behavior reminiscent of a traditional princess.

Both the images and the text analysed in this part of the story challenge the traditional princess stereotype, contradicting our expectations about fairytales. The discrepancy between the expectations set up in the verbiage and the visuals on the one hand, and our knowledge of other fairy tales on the other leads to the emergence/creation of irony.

\subsubsection{Incongruities between text and images: Counterpointing interaction}

While the previous section deals with the incongruities between Princess Smartypants and other fairytales, this section focuses on the incongruities that arise between the text and the images and the predominant kind of interaction. As indicated in section 1.2., in counterpointing interaction words and images provide 'alternative information' and collaborate to communicate meanings beyond the scope of either one standing alone (Nikolajeva and Scott 2000). Moya and Pinar (2009) adopt Nikolajeva and Scott's $(2000,2001)$ types of counterpointing interaction: ironic and perspectival counterpoint, the second part of Princess Smartypants being rich in ironic counterpoint. 
Following Shanks (2008), Princess Smartypants fulfills her name when she cleverly outwits the usual authorities within a typical princess book: her parents and her suitors. As Shanks (2008: 30) indicates, "she does this by creating challenges that the princes must complete before they can enter into a marriage that she clearly dislikes but that her parents insist on having". Each task seems easy. However, there is something that makes it difficult. As Nikolajeva and Scott (2001: 19) point out, the tasks the princess gives her many suitors are described by words: "stop the slugs from eating her garden", "feed her pets", "challenged $[\ldots]$ to a roller disco marathon", "invited [...] for a cross-country ride on her motorbike", "rescue her from her tower", "chop some firewood in the royal forest", "put her pony through its paces", "take her mother, the Queen, shopping" and "retrieve the magic ring from the goldfish pond". The pictures show us how each prince failed: the slug is as large as a dinosaur, her pets are a horde of fierce dragons, the tower is made of glass, the forest is enchanted, the goldfish pond is inhabited by an enormous shark, and so on (Nikolajeva and Scott 2001: 20). As Nikolajeva and Scott (2001: 20) state, "in each case, the words antedate the picture; the picture is the result of what is decreed by words". This interaction creates the ironic humour that characterizes Princess Smartypants.

Thus, Prince Compost has to kill the slugs eating the garden. His name refers to decayed organic material used as fertilizer for growing plants. Bearing in mind that the name is related to gardening and agriculture and that what he has to do is to eliminate a normal creature that usually inhabits in gardens, the first thought coming to our mind is that the prince will carry out the task without any problems. However, when we look at the picture, we find the opposite. There is just one slug, as big as a dinosaur, with sharp teeth. The prince is represented in a very small size (in order to show his insignificance), with some gardening tools which will be completely useless to face this task.

The second prince's name is Rushforth, to do something with urgent haste. Once again the pictures show that his speed is useless and the image only shows his legs when he is leaving the page. The third prince's name, Prince Pelvis, is most likely motivated by Elvis Presley, whose nickname was Elvis the Pelvis. The text says: "She challenged Prince Pelvis to a roller-disco marathon". As soon as we look at the picture, we realize that Prince Pelvis is totally opposed to Elvis Presley. He appears lying on his back, with green face and puffing, showing his inability to dance. In addition, they go to a roller-disco marathon rather than to a ball, where, according to the tradition, princesses go. The short and colourful dress she is wearing is not the kind of dress typically associated with princesses. Once again there are two orders of reality and associated beliefs which are not fulfilled. In this case there is also an incongruity between the fairytale and cultural and generic conventions.

Boneshaker refers to an old vehicle, with poor suspension, an early type of bycicle without rubber tyres. Despite having a name related to the task he has to accomplish, Prince Boneshaker is unable to ride across the country on the princess' 
motorbike, since, when they fly over a river full of snake-like animals with really sharp teeth, he is terribly afraid.

Prince Bashthumb derives his name from bash "heavy blow" and thumb "the short, thick, first digit of the hand". His task is to chop some firewood in the royal forest, but as the picture shows, he does not even have time to bash his thumb.

Prince Fetlock is unable to tame the princess' pony, whereas Prince Grovel (his name meaning "to act obsequiously to obtain forgiveness or a favor") acts accordingly with the Princess' mother and is kneeled down in a lingerie department, carrying all the Queen's bags. The intertextual references in the visual part are clear. In the British edition, we can see "Harrolds" printed on one of the shopping bags, referring to the famous department store "Harrods" in London, whereas in the American version it is printed "Lacy's", referring to Macy's in New York. Prince Swimbladder's name refers to a gas-filled sac in a fish's body, used to maintain buoyancy. With this feature, it should be easy to retrieve the princess' ring from the pond, but the images show us his inability to do it. After all these tasks, "[n]one of the princes could accomplish the task he was set. They all left in disgrace. Smartypant's face irradiates happiness.

The analysis of this second part reveals that the text anticipates the tasks the suitors must fulfill while the visuals depict the outcome. The resolution of the incongruity between the images and the text as well as the discrepancies between the expectations set up by the princes/ names and their (in)abilities dominate this part.

In the third part of the story, Prince Swashbuckle manages to carry out all the tasks successfully. The words state only that he accomplishes all the tasks, while the pictures show exactly how he manages it, as Nikolajeva and Scott (2001:20) point out, "with a great deal of humor and inventiveness in detail". This part is rich in ideational complementarity, where pictures illustrate the meanings transmitted in the verbiage. "He stopped the slugs eating her garden [...] fed her pets $[\ldots]$ roller discoed until dawn $[\ldots]$ rode for miles on her motorbike $[\ldots]$ he rescued her from her tower", etc. There is a simultaneous succession of images that depicts moments which are disjunctive in time but are perceived as belonging together, in an unequivocal order. The changes occurring in each subsequent image are supposed to indicate the flow of time between it and the preceding one (Sell 2002: 97). This rapid succession depicts how he really manages to accomplish the different tasks, which adds irony and makes fun of the concept of bravery he shows (see Figure 4). First of all, in order to stop the slugs eating the garden, instead of fighting as a brave prince is supposed to do, he gives the slugs some alcoholic drink. To feed the three big dragons, he flies over them in a helicopter throwing some bones on his way. He is able to ride on Smartypants' motorbike because he covers his eyes in order not to see what is going on around him. $\mathrm{He}$ also finds a solution to climb the glassy tower, by using suction caps. He does not need to carry the Queen's heavy purchase since three huge elephants will do it for him. As the pictures show, the facial expression of the princess has totally changed, whereas the prince shows an expression of victory and pride. Humor results from the unconventional solutions the prince finds. Therefore, mention 
has also to be made to a series of deviations from what is expected on the basis of our generic and world knowledge.

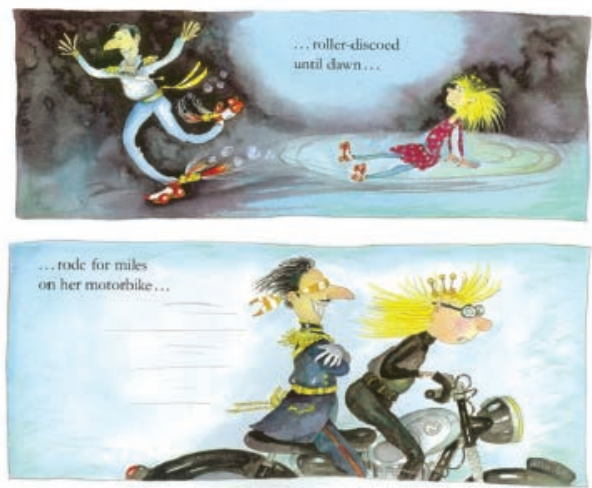

Figure 4. Prince Swashbuckle's resolution

The verbal story ends by stating that "she lived happily ever after", the pictures expanding the words by showing the princess smiling broadly, leaning back in a beach chair, wearing a red bikini and surrounded by her pets (Nikolajeva and Scott 2001: 20). This image is significant as it implies she has now established a position of freedom. She has successfully avoided the social contract of marriage, and challenged the authority of the adult world.

As mentioned before, ironic counterpoint dominates this section. The resolution of the incongruity between the words and the images, based on background knowledge and assumptions is an indicator both of humor and irony.

\section{Conclusion}

The aim of the paper was to establish the way irony and humor are produced in Princess Smartypants. In order to do so, an analysis of the fairytale has been carried out taking into account two types of incongruities: incongruity between this fairytale and other fairytales and incongruities between text and image within the fairytale itself. The analysis has shown that Princess Smartypants invites different interpretations and readings and requires the reader's involvement to fill the 'readerly gaps', to identify and solve the incongruities, which provoke irony and humor. The analysis has also shown that the ironic meaning is arrived at inferentially and independently from the literal meaning of the utterance or the image. Another aspect to highlight is that recognition of the irony usually comes from cues in the context or from background knowledge. The paper has addressed issues which had hardly been mentioned in the study of picturebooks and opens up 
new lines of research related to the cognitive mechanisms involved in children's and adults' appreciation of humor and irony and the way (postmodern) picturebooks are interpreted.

\section{Notes}

1 The verso is the lefthand pages of a book, bearing the even numbers, whereas the recto is the right-hand pages of a book, bearing the odd numbers, Doublespreads are the two facing pages of a publication treated as a single unit. As Sell (2002: 98) points out, the creator may use the tension between the verso and the recto and quite often the verso creates a sense of security, while the recto brings danger and excitement.

2 The distribution does not necessarily correspond to an image per page: we find five doublespreads, four of which need to be treated as a single unit and the last one is made of four images (see Figure 3), 11 pages on the verso position which contain 13 images, and 10 pages on the recto position which contain 12 images. The cover and wallpaper images have also been analysed.

Norton is a well-known motorcycle brand in the UK and the logo is depicted in the image.

\section{References}

Andrew, Patricia (2012) 'Laughter is the Best Medicine'. The construction of Old Age in Ageist Humor'. In: Jan Chovanec and Isabel Ermida (eds.) Language and Humor in the Media. Cambridge Scholars Publishing.

Anstey, Michele (2002) 'It's not All Black and White': Postmodern Picturebooks and New Literacies.' Journal of Adolescent and Adult Literacy 45 (6), 444-457.

Attardo, Salvatore (2000) 'Irony as relevant inappropriateness'. Journal of Pragmatics 32, 793826.

Attardo, Salvatore (2001) Humorous Texts: A Semantic and Pragmatic Analysis. Boston and New York: Mouton de Gruyter.

Bader, Barbara. (1976) American Picturebooks from Noah's Ark to the Beast within. New York: Macmillan.

Beauvais, Clementine (2015) 'What's in "the gap"?A glance down the central concept of picturebook theory'. Nordic Journal of Childlit Aesthetics, 6.

Colston, Herbert L. and Jennifer O'Brien (2000) 'Contrast and pragmatics in figurative language: anything understatement can do, irony can do better'. Journal of Pragmatics 32, 1557-1583.

Culler, Jonathan (1975) Structuralist Poetics: Structuralism, Linguistics, and the Study of Literature. Ithaca: Cornell UP.

Davies, Bronwyn (1989) Frogs and Snails and Feminist Tales: Preschool Children and Gender. Sydney: Allen and Unwin.

Dombey, Henrietta (1992) 'Lessons learnt at Bedtime'. In: Keith Kimberley, Margaret Meek and Jane Miller (eds.) New Readings: Contributions to an Understanding of Literacy. London: A. \& C. Black, 29-36.

Dresang, Eliza T. (1999) Radical change: Books for youth in a digital age. New York: H. W. Wilson.

El Refaie, Elisabeth (2009) 'What makes us lagh? Verbo-visual Humour in Newspaper Cartoons'. In: Eija Ventola and A. Jesús Moya (eds.) The World Told and The World Shown. Multisemiotic Issues. Basingstoke: Palgrave, 75-89. 
Feaver, William (1977) When we were Young: Two Centuries of Children's Book Illustrations. London: Thames and Hudson.

Flieger, Jerry A. (1991) The Purloined Punch Line: Freud's comic theory and the Postmodern Text. Baltimore, MD: The John Hopkins University Press.

Gibbs, Raymond and O'Brien, Jennifer (1991) 'Psychological aspects of irony understanding.' Journal of Pragmatics 16 (6), 523-530.

Giora, Rachel (1995) 'On Irony and Negation'. Discourse Processes 19, 239-264.

Giora, Rachel (2000) 'Irony'. In: Jef Verschueeren, Jan-Ola Östman and Jan Blommaert (eds.) Handbook of Pragmatics. Amsterdam: John Benjamins.

Goldstone, Bette P. (1999) Brave new worlds: The changing image of the picture book. New Advocate $12,331-344$.

Goldstone, Bette P. (2002) 'Whaz up with our books? Changing picture book codes and teaching implications'. The Reading Teaching 55, 362-369.

Grice, H. Paul (1989) Studies in the Way of Words. Cambridge, MA: Harvard University Press.

Grieve, Ann (1993) 'Postmodernism in Picturebooks'. Papers: Explorations into Children's Literature 4 (3), 15-25.

Iser, Wolfgang (1974) The implied Reader. Patterns of Communication in Prose Fiction from Bunyan to Beckett. Baltimore: John Hopkins University Press.

Johnson, Samuel (1755 [2006]). A Dictionary of the English Language: An Anthology. Ed. David Crystal. London: Penguin Classics.

Kümmerling-Meibauer, Bettina (1999) 'Metalinguistic Awareness and the child developing concept of irony: The Relationship between Pictures and Text in Ironic Picture Books'. The Lion and the Unicorn. A Critical Journal of Children's Literature 23 (2), 157-183.

Lewis, David (1996) 'Going Along with Mr Gumpy: Polysystemy and Play in the Modern Picture Book'. Signal 80, 105-119.

Lewis, David (2006 [2001]) Reading contemporary picturebooks: Picturing text. London: Routledge Falmer.

Moebius, William (1986) 'Introduction to picture books' codes'. Word and Image 2 (2), 141-158.

Moya, A. Jesús (2014) A Multimodal Analysis of Picture Books for Children. A Systemic Functional Approach. London: Equinox.

Moya, A. Jesús and María J. Pinar (2008) 'Compositional, interpersonal and representational meanings in a children's narrative. A multimodal discourse analysis'. Journal of Pragmatics 40 (9), $1601-1619$.

Moya, A. Jesús and María J. Pinar (2009) 'On interacton of image and verbal text in a picture book. A multimodal and systemic functional study'. In: Eija Ventola and A. Jesús Moya (eds.) The World Told and the World Shown: Multisemiotic Issues. London: Palgrave Macmillan, 107-123.

Nikolajeva, Maria (2008) 'Play and Playfulness in Postmodern Picturebooks'. In: Lawrence Sipe and Sylvia Pantaleo (eds.) Postmodern Picturebooks. Play, Parody and Self Referentiality. New York and London: Routledge, 55-74.

Nikolajeva, Maria and Carole Scott (2000) 'The dynamics of picturebook communication'. Children's Literature in Education 31 (4), 225-239.

Nikolajeva, Maria and Carole Scott (2001) How Picturebooks Work. New York and London: Garland Publishing.

Nodelman, Perry (1988) Words about pictures: The narrative art of children's picture books. Athens: University of Georgia Press.

Painter, Claire, Jim Martin and Leo Unsworth (2013) Reading Visual Narratives. Image Analysis of Children's Picture Books. Sheffield and Bristol, CT: Equinox.

Pantaleo, Sylvia (2004) 'Young children and radical change characteristics in picture books'. Reading Teacher 58 (2), 178-187. 
Pantaleo, Sylvia and Lawrence Sipe (2008) 'Introduction. Postmodernism and picturebooks'. In: Lawrence Sipe and Sylvia Pantaleo (eds.) Postmodern Picturebooks. Play, Parody, and SelfReferentiality. New York and London: Routledge.

Quintilian, Marcus F. (1999) Instituciones Oratorias. Ed. Alfonso Ortega Carmona. Salamanca: Universidad Pontificia.

Raskin, Victor (1985) Semantic Mechanisms of Humor. Dordrecht-Boston-Lancaster: D. Reidel.

Roche, Mary (2015) Developing Children's Critical Thinking through Picturebooks: A guide for primary and early years students and teachers. London and New York: Routledge.

Schaffer, Rachel (1982) Vocal clues for irony in English. Unpublished Ph.D. dissertation, Ohio State University.

Scott, Biljana (2004) 'Picturing irony: The subversive power of photography'. Visual Communication 3 (31), 31-59.

Sell, Roger (2002) Children's Literature as Communication. The ChiLPA Project. Amsterdam and Philadelpia: John Benjamins.

Shanks, Caitlin (2008) 'Gender roles and the Princess in American Literature and Society'. The Journal of Undergraduate Research. University of Kansas, 25-34.

Siddall, Jane (1997) Postmodernism and Children's Picture books. Unpublished thesis. Edith Cowan University.

Sipe, Lawrence (1998) 'How Picture Books work: A Semiotically Framed Theory of Text-Picture Relationships.' Children's Literature in Education 29 (2), 97-108.

Sipe, Lawrence and Sylvia Pantaleo (eds). (2008) Postmodern Picturebooks. Play, Parody and Self Referentiality. London and NewYork: Routledge.

Sperber, Dan and Deirdre Wilson (1981) 'Irony and the use-mention distinction'. In: Peter Cole (ed.) Radical Pragmatics. New York: Academic Press, 295-318.

Unsworth, Leo (2008) 'Explicating intermodal meaning-making in media and literary texts: Towards a metalanguage of image/text relations'. In: Andrew Burn and Cal Durrant (eds.) Media Teaching: Language, Audience, Production. London: AATE-NATE and Wakefield Press, 48-80.

Van Meerbergen, Sara (2012) 'Play, parody, intertextuality and interaction: Postmodern Flemish picture books as semiotic playgrounds'. Nordic Journal of ChildLit Aesthetics, 3. http://dx.doi. org/10.3402/blft.v3i0.20075.

Wolfenbarger, Carol D. and Lawrence Sipe (2007). 'A Unique Visual and Literary Art Form: Recent Research on Picturebooks'. Language Arts 83 (3), 273-280.

Yus, Francisco (2016) Humour and Relevance. Topics in Humour Research. Amsterdam and Philadelpia: John Benjamins.

María Jesús Pinar Sanz is a Lecturer in Linguistics and Discourse Analysis at the University of Castilla-La Mancha (Spain). Her research interests are in multimodal discourse analysis and, more specifically, in aspects related to the analysis of election campaigns, political advertising and ethnic humor. She has published several articles on the generic structure of political ads, ethnic humor and the relationship between the verbal and visual elements not only in political texts but also in children's narratives. She is the editor of Multimodality and Cognitive Linguistics, a special issue of Review of Cognitive Linguistics 11 (2) published by John Benjamins.

Address: Dr. María Jesús Pinar Sanz. Facultad de Letras. Avda Camilo José Cela s/n. 13071 Ciudad Real, Spain. [mariajesus.pinar@uclm.es]

Arsenio Jesús Moya Guijarro is a Senior Lecturer in the Department of English Language and Linguistics, University of Castilla La Mancha (Spain). He is co-editor, with Eija Ventola, of The World Told and the World Shown: Multisemiotic Issue (Palgrave Macmillan, 2009) and the author 
of A Multimodal Analysis of Picture Books for Children. A Systemic Funcional Approach (Equinox, Discussion in Functional Approaches to Language, 2014). He has published several articles on information, thematicity and multimodal discourses in international journals such as Word, Text, Functions of Language and Journal of Pragmatics.

Address: Dr. A. Jesús Moya Guijarro. Faculty of Education. University of Cuenca, Campus Universitario s/n. 16071 Cuenca, Spain. [email:arsenio.mguijarro@uclm.es] 
